\title{
HOME IS WHERE THE HEART IS: FACTORS DETERMINING FAMILY DEMAND AND ITS IMPLICATIONS FOR HRM PRACTICES
}

\author{
Navaneethakrishnan Kengatharan* \\ University of Jaffna
}

\begin{abstract}
A plethora of studies on family demands that have been investigated in the Western countries are reflective of such cultural contexts limiting its applicability to another cultural context. The factors determining family demand where conflict originates are country-culture specific and consequently, anchored in the conservation of resource theory, the present study aims to discover the factors making a significant variance in family demand. Strongly based on the ontological and epistemological assumptions, the study adopted a survey strategy with a deductive approach in a cross-sectional time horizon. Data were garnered from 487 banking employees with a self-reported questionnaire. The present study reveals that hours spent on household chores, hours spent on childcare, hours spent on dependents, and gender have significantly impacted family demand, nonetheless, formal and informal organisational supports have alleviated the level of family demand. Remarkably, the study affirms the prevalence dogma of traditional gender role ideology and women's position in a collectivist cultural context. Surprisingly, the number of children, number of dependents, marital status and age were not found as predictors of family demand. The findings of the study have proffered many useful practical implications for HRM practices.
\end{abstract}

Keywords: Conservation of resource theory; Family demand; Formal organisational support; Informal organisational support

Received: 1 July 2019

Accepted: 30 December 2019

\section{INTRODUCTION}

Studies on work and family mutual interference are of growing importance in the fields of organisational studies and human resource management owing to its insidious effect on both family and work (Annor \& Burchell, 2018; Chau, 2019; Lambert, Qureshi, Keena, Frank, \& Hogan, 2019; Lee, Grace, Sirgy, Singhapakdi, \& Lucianetti, 2018; Pan \& Yeh, 2019; Zhao, Zhang, \& Foley, 2019). Generally, work allows families to support themselves and offers many psychological rewards for individual family members (Kossek \& Ozeki, 1998). Thus, work and family are interdependent and where the performance of work roles impacts on family roles or family roles on work roles, work-family conflict is generated. Work-family conflict has been defined as 'a form of inter-role conflict in which the role pressures from the work and family domains are mutually incompatible in some respects' (Greenhaus \& Beutell, 1985, p.77). Thus, work-family conflict

\footnotetext{
* Corresponding Author: Navaneethakrishnan Kengatharan, Department of Human Resource Management, University of Jaffna, Sri Lanka. Email: kenga@univ.jfn.ac.lk
} 
(WFC) focuses on the difficulties employees have in balancing their work and family responsibilities (Adams, King, \& King, 1996). In the early 1980s, work-family conflict has been treated as a unidirectional concept (e.g. Kopelman, Greenhaus, \& Connolly, 1983; Cooke \& Rousseau, 1984). However, later work-family conflict has been considered as a "bidirectional concept": work to family conflict and family to work conflict (e.g. Carlson, Kacmar, \& Williams, 2000; Kelloway, Gottlieb, \& Barham, 1999; Netemeyer, Boles, \& McMurrian, 1996). Consequently, family and work domains have become predominantly vital and thus work-family conflict is defined as the incompatibility of both domains such that participation in one role makes it difficult to meet demands in the other (Greenhaus \& Beutell, 1985). Variables determining family and work domains are subject to country-culture specific nature and therefore, findings of the studies that have been undertaken in the west, are not applicable in another cultural context.

Surprisingly, comparing individualist nations such as Anglo, Nordic Europe, Germanic Europe, Latin Europe, Latin America with collectivist nations such as Eastern Europe, Confucian Asia, Southern Asia, Middle East and Subsaharan Africa, a few studies have been investigated in the context of collectivist culture, for example, only $4.2 \%$ of research studies are representing Southern Asia in the realm of family and work (Shockley et al., 2017). The family and work contexts vary across nations in many ways. The collectivists view that family is the people's identities and have greater family demand since family care is left to the families where organisational supports are not well developed (Hassan, Dollard, \& Winefield, 2010; Mortazavi, Pedhiwala, Shafiro, \& Hammer, 2009; Oishi, Chan, Wang, \& Kim, 2015). The dogma of traditional gender role ideology paints a vivid picture of Asian countries (e.g. Dasgupta, 1998; Hofstede, Hofstede, \& Minkov, 2010; Kulik, 2004; Nameda, 2013). Similarly, in a collectivist culture, on the one hand, extended family members share family responsibilities, on the other hand, extended family members demand extra family burden in the form of eldercare and other obligations (see Poster \& Prasad, 2005) and therefore, the family demand might vary. In contrast, individualism and value of gender egalitarianism where men and women share equal responsibilities at work and family are the unique characteristics of the Western countries (Hofstede et al., 2010). These cultural differences might have an impact on family demand and therefore, seminal studies warn the applicability of the findings from one culture to another (e.g. Choi, 2008, Hassan et al., 2010). Surprisingly, factors determining family demand in collectivist culture have not been heretofore examined. Therefore, the current study responds to the acknowledgement of the needs.

The present study is strongly based on the conservation of resource theory (COR) that postulates that individuals strive to acquire, maintain and protect resources and when the threat of resource loss creates stress (Hobfoll, 1989). Therefore, in a family, individual consumes resources in executing family responsibilities such as time spent on household chores, number of children, hours spent on children, main child's carer, number of dependents needing care, hours spent on dependents, primary dependent's carer, working spouse, spouse working hours, main earner, number of family members, and nature of family. Consequently, the study fills lacuna left by earlier studies by discovering the factors making a significant variance in family demand.

\section{THEORETICAL UNDERPINNINGS}

Seminal studies in the sphere of work-family conflict have found that family domain originates family to work conflict implying that family demand that employees have interfere with their 
performance at work (e.g. Carlson et al., 2000; Frone, Russell, \& Cooper, 1992; Gutek, Searle, \& Klepa, 1991; Kelloway et al., 1999; Netemeyer et al., 1996; Williams \& Alliger, 1994). Family demand refers to the physical and psychological works that are expected by the members of the family at home like housekeeping and childcare (see Yang, Chen, Choi, \& Zou, 2000). Studies found a high level of family demand in some countries and lower in other countries. For example, family demand is greater among American employees than Chinese employees (Yang et al., 2000). However, what was little focused is the factors that cause family demand. Emslie and Hunt (2009) conducted semi-structured interviews specifically with middle-aged men and women (aged 50 to 52 years) and found that women perform varieties of tasks at home (despite having no young children at home) and thus experience more family demand than men. Some studies found that there is relationship between age and work-family conflict (e.g. Voydanoff, 2005). However, other studies did not make any strong relationship (e.g. Frone, Russell, \& Cooper, 1997). Interestingly, Grzywacz and Marks' (2000) study claims that young women have a greater burden of the family than older women. Albeit the conflicting conclusions of previous studies in identifying the relationship between age and family demand, family demand would be expected to increase as individuals get aged. In a similar vein, a few studies found marital status would determine family demand (e.g. Boyar, Maertz, Mosley, \& Carr, 2008; Schieman, Whitestone, \& Van Gundy, 2006). It would be expected that married individuals will have more family demand in the form of family obligations as a spouse than individuals who are not married (Boyar et al., 2008). Nonetheless, the effect of age and marital status on family demand has not been established in nations with collectivist culture.

Previous studies lent credence to the view that the presence of children and dependent care increases family demand (e.g. Boyar et al., 2008; Carlson, 1999; Foley, Hang-Yue, \& Lui, 2005; Goff, Mount, \& Jamison, 1990; Grzywacz \& Marks, 2000; Hammer, Allen, \& Grigsby, 1997; Hoobler, Wayne, \& Lemmon, 2009; Lu, Gilmour, Kao, \& Huang, 2006). In a family, parents spend time and energy to look after their children and thus, the number of children that a family has, was found as a significant contributor of the family demand, nonetheless, some studies did not find any significant relationship (see Boyar et al., 2008). The nature and the strength of the relationship can be attributed to country-culture specific nature, and there is bereft of the studies in the case of a collectivist culture where the extended family is the hallmark. In contrast, dependent care would be additional burden within an extended family structure. Agarwala, Arizkuren-Eleta, Del Castillo, Muniz-Ferrer and Gartzia (2014) claim that childcare and elder caring responsibilities were greater in India (collectivist cultural nation) than Spain and Peru.

Studies on the factors contributing to family demand are scant and taken previous studies together, it is expected that factors such as hours spent on household chores, number of children, hours spent on children, main child's carer, number of dependents needing care, hours spent on dependents, primary dependent's carer, working spouse, spouse working hours, main earner, number of family members, nature of family, and gender could determine family demand. On balance, family demand is varying and subject to country-culture specific nature. A systematic study on factors determining family demand has not been heretofore explored in countries with collectivist culture. Consequently, the present study raises a question that what factors are accounted for the variance in family demand. 


\section{METHODS}

\subsection{Sampling and Respondents}

Data were garnered from randomly selected 487 employees working in the banking sector. For robustness, based on the Fitch rating report, 9 banks were purposively chosen to cover the range of variation in the banking sector. Of the 487 respondents, men accounted for $58 \%(n=285)$ and the remaining $42 \%(n=202)$ were females. Chi-square test has been performed to see the sample is the representation of the population. The expected values $(\mathrm{E})$ calculated were compared with the observed values $(\mathrm{O})$. The sum of the calculated Chi-square value $\left(\sum(\mathrm{O}-\mathrm{E})^{2} / \mathrm{E}=1.24\right)$ is less than the Chi-square table value $\left(\chi^{2}(1)=1.24 ; \chi^{2}<\right.$ Critical value of $\left.3.84, p=.05\right)$ indicating that there is no significant difference between the observed and expected number of males and females that imply that the sample is the representation of the population. As for ages and marital status of respondents, a large number of respondents were between 26 to 35 years $(41.1 \%)$ and $84 \%$ were married $(n=408)$. Regarding the educational qualification, men have slightly high educational qualifications than that of female counterparts.

\subsection{Instruments}

Family demand was measured using two questions adopted from Boyar, Carr, Mosley, \& Carson (2007) and one question has been developed. The items include: (1) I have to work hard on familyrelated activities; (2) I never seem to have enough time to get everything done at home; and (3) I feel like I have a lot of family demand. The respondents were asked to indicate their agreeableness on each statements using a five-point Liker scale ranging from strongly disagree (1) to strongly agree (5). The Cronbach's alpha is .87 indicating strong reliability of the scale.

Hours spent on household chores, hours spent on children, hours spent on dependents and spouse working hours were measured in number of hours as continuous variables. Similarly, number of children, number of dependents needing care, and number of family members were measured in terms of numbers. Coding system was applied to measure other variables: Main child's carer (1=Others; 2=Respondent); Primary dependent's carer (1=Others; 2=Respondent); Working spouse $(1=\mathrm{No} ; 2=\mathrm{Yes})$; Main earner $(1=\mathrm{No} ; 2=\mathrm{Yes})$; Nature of family $((1=$ Single; $2=$ Couple $)$; Formal work-life policies ( $1=\mathrm{No} ; 2=\mathrm{Yes})$; Informal work-life policies $(1=\mathrm{No} ; 2=\mathrm{Yes})$; and Gender (1=Male; $2=$ Female).

\section{RESULTS}

Taken the advice of Adams, Khan, Raeside and White (2007) and Blumberg, Cooper and Schindler (2008), prior to conducting an extensive large scale study, a small scale pilot study with twenty respondents has been undertaken to ensure that the questionnaire is clear to the respondents. Based on the pilot study, a few questions were modified since the respondents struggled to understand the question in the way it intended to measure. Having collected the data, fundamental assumptions were examined to ensure the suitability of the statistical tests employed. The value of DurbinWatson statistic 1.768 is better (table 2) indicating errors in regression are independent. Furthermore, the plot of *ZRESID against *ZPRED, histogram and normal probability plot of the residuals were examined and the results have met the assumptions of linearity, homoscedasticity 
and normality (See figure 1). The variance inflation factor (VIF) and tolerance were examined to see if multicollinearity is an issue. As can be seen in Table 4, VIF values are all well below 5 (maximum VIF value is 1.460) and similarly all tolerance statistics are well above 0.2 (minimum value of tolerance .685) indicating no multicollinearity between predictors suggesting that the model is capable of assessing the individual importance of each predictor.

Figure 1: Family Demand- Checking Assumptions of Linearity, Homoscedasticity and Normality

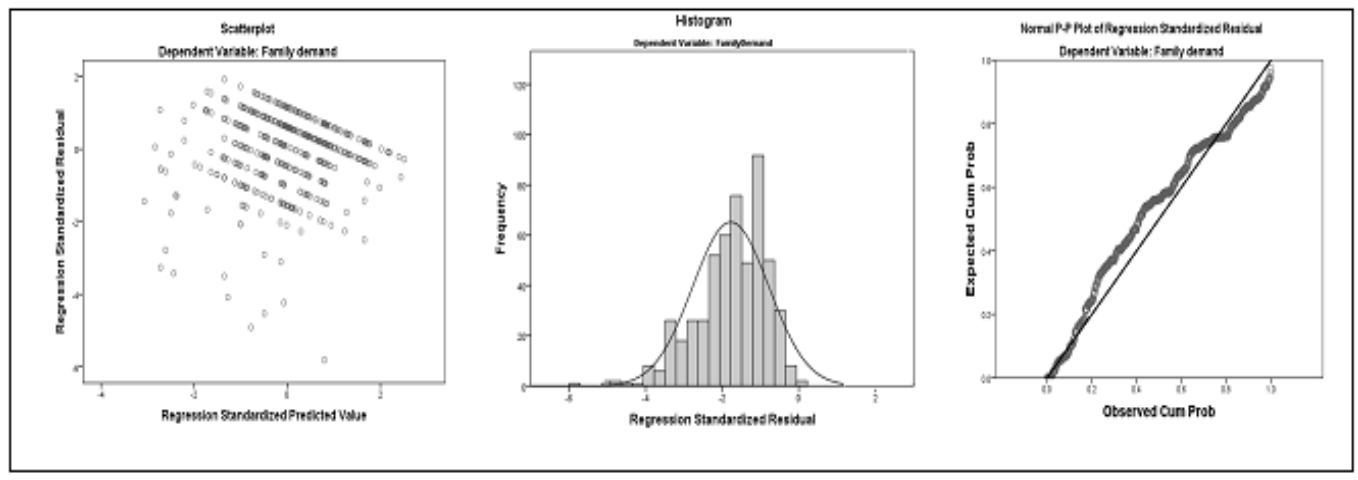




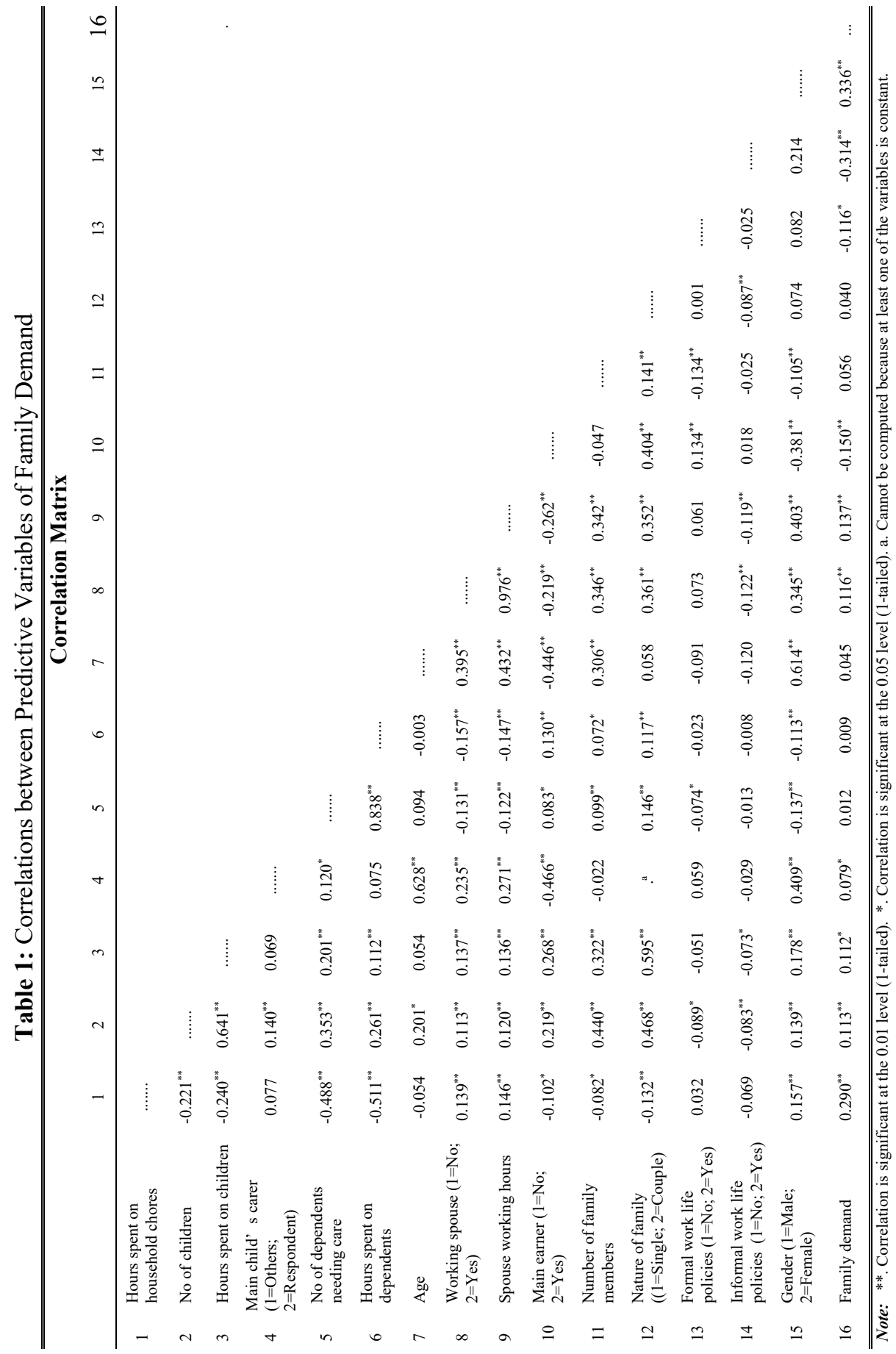


The results of the correlation analysis between such potential predictors and family demand are presented in Table 1. The results revealed that hours spent on household chores $(r=.29, p<0.01)$ and being female $(r=.34, p<0.01)$ were strongly positively associated with family demand whereas informal work-life policies $(r=-.31, \mathrm{p}<0.01)$ was strongly negatively associated with family demand. Further, number of children $(r=.11, p<0.01)$, hours spent on children $(r=.11, p<0.05)$, main child's carer (respondent) $(r=.08, p<0.05)$, working spouse $(r=.12, p<0.01)$, spouse working hours $(r=.14, p<0.01)$ were significantly positively associated with family demand however the associations were weak. The association of formal work-life policies with family demand was significantly negatively weak $(r=-.12, p<0.05)$ suggesting little effect. Nonetheless, the number of dependents needing care, hours spent on dependent care, primary dependent's carer, nature of family (living couple) and number of family member were not found to be significantly associated with family demand.

In the next stage, the potential predictors of family demand viz., hours spent on household chores, hours spent on childcare, hours spent on dependent, number of dependents, number of children, formal work-life policies, informal work-life policies, age, marital status, spouse working and gender were examined using stepwise multiple regression analysis. The stepwise multiple regression analysis is the most popular sequential approach to variable selection and to examine the contribution of each independent variable and thus facilitates addition or deletion of variables at each stage (Hair, Black, Babin, \& Anderson, 2010). Surprisingly, the number of children, number of dependents, age, spouse working and marital status were not significantly related to family demand and thus those variables were excluded in the final model. Table 2 depicts the variance explained by each of the 6 remaining predictor variables.

Table 2: Model Summary: Predictors of Family Demand Model Summary ${ }^{\mathrm{g}}$

\begin{tabular}{cccccc}
\hline \hline Model & $\boldsymbol{R}$ & $\boldsymbol{R}$ Square & Adjusted $\boldsymbol{R}$ Square & $\begin{array}{c}\text { Std. Error of the } \\
\text { Estimate }\end{array}$ & Durbin-Watson \\
\hline 1 & $.314^{\mathrm{a}}$ & .098 & .097 & .669 \\
2 & $.332^{\mathrm{b}}$ & .110 & .106 & .666 \\
3 & $.429^{\mathrm{c}}$ & .184 & .179 & .638 \\
4 & $.496^{\mathrm{d}}$ & .246 & .240 & .614 & \\
5 & $.529^{\mathrm{e}}$ & .279 & .272 & .601 & \\
6 & $.539^{\mathrm{f}}$ & .290 & .281 & .597 & $\mathbf{1 . 7 6 8}$ \\
\hline \hline
\end{tabular}

a. Predictors: (Constant), Informal Policies

b. Predictors: (Constant), Informal Policies, Formal Policies

c. Predictors: (Constant), Informal Policies, Formal Policies, hours spent on household chores

d. Predictors: (Constant), Informal Policies, Formal Policies, hours spent on household chores, Gender

e. Predictors: (Constant), Informal Policies, Formal Policies, hours spent on household chores, Gender, hours spent on dependent

f. Predictors: (Constant), Informal Policies, Formal Policies, hours spent on household chores, Gender, hours spent on dependent, hours spent on children

g. Dependent Variable: Family demand

Inclusion of all six variables explains $29 \%$ of variance (Model 6: $R^{2}=.290$ ) in family demand although the remaining $71 \%$ of variance in family demand is not explained by this model. 
However, the value of $R^{2}(.290)$ produced the effect size of Cohen's $f^{2} .408$ is indicative of largesized effect. The value of Stein's equation is $27.06 \%$ which is closer to the observed value of $R^{2}(.290)$ indicating that the cross-validity of the model is reasonably good.

Table 3: ANOVAg- Predictors of Family Demand

\begin{tabular}{|c|c|c|c|c|c|c|}
\hline Model & & Sum of Squares & df & Mean Square & $\mathrm{F}$ & Sig. \\
\hline \multirow[t]{3}{*}{1} & Regression & 23.736 & 1 & 23.736 & 52.974 & $.000^{\mathrm{b}}$ \\
\hline & Residual & 217.314 & 485 & .448 & & \\
\hline & Total & 241.050 & 486 & & & \\
\hline \multirow[t]{3}{*}{2} & Regression & 26.538 & 2 & 13.269 & 29.939 & $.000^{c}$ \\
\hline & Residual & 214.512 & 484 & .443 & & \\
\hline & Total & 241.050 & 486 & & & \\
\hline \multirow[t]{3}{*}{3} & Regression & 44.406 & 3 & 14.802 & 36.357 & $.000^{\mathrm{d}}$ \\
\hline & Residual & 196.644 & 483 & .407 & & \\
\hline & Total & 241.050 & 486 & & & \\
\hline \multirow[t]{3}{*}{4} & Regression & 59.415 & 4 & 14.854 & 39.417 & $.000^{\mathrm{e}}$ \\
\hline & Residual & 181.635 & 482 & .377 & & \\
\hline & Total & 241.050 & 486 & & & \\
\hline \multirow[t]{3}{*}{5} & Regression & 67.371 & 5 & 13.474 & 37.317 & $.000^{\mathrm{f}}$ \\
\hline & Residual & 173.679 & 481 & .361 & & \\
\hline & Total & 241.050 & 486 & & & \\
\hline \multirow[t]{3}{*}{6} & Regression & 69.956 & 6 & 11.659 & 32.710 & $.000^{\mathrm{g}}$ \\
\hline & Residual & 171.094 & 480 & .356 & & \\
\hline & Total & 241.050 & 486 & & & \\
\hline
\end{tabular}

a. Predictors: (Constant), Informal Policies

b. Predictors: (Constant), Informal Policies, Formal Policies

c. Predictors: (Constant), Informal Policies, Formal Policies, hours spent on household chores

d. Predictors: (Constant), Informal Policies, Formal Policies, hours spent on household chores, Gender

e. Predictors: (Constant), Informal Policies, Formal Policies, hours spent on household chores, Gender, hours spent on dependent

f. Predictors: (Constant), Informal Policies, Formal Policies, hours spent on household chores, Gender, hours spent on dependent, hours spent on children

g. Dependent Variable: Family demand

As shown in Table 3, the value of $F$ statistics are highly significant for all six models: $F(485)=52.974, p<.001), F(484)=29.939, p<.001), F(483)=36.357, p<.001), F(482)=39.417$, $p<.001), F(481)=37.317, p<.001)$ and $F(480)=32.710, p<.001)$ respectively, indicating that the initial model is significantly improved and thus model 6 was chosen as the best model. Coefficients of the predictors determining family demand are presented in table 4. 
Table 4: Unstandardized Coefficients and Standardized Coefficients of the Predictors of Family Demand

\begin{tabular}{|c|c|c|c|c|c|c|c|c|}
\hline \multicolumn{9}{|c|}{ Coefficients $^{\mathbf{a}}$} \\
\hline \multirow{2}{*}{\multicolumn{2}{|c|}{ Model }} & \multicolumn{2}{|c|}{$\begin{array}{c}\text { Unstandardized } \\
\text { Coefficients }\end{array}$} & \multirow{2}{*}{$\begin{array}{c}\text { Standardized } \\
\text { Coefficients }\end{array}$} & \multirow[t]{2}{*}{$t$} & \multirow[t]{2}{*}{ Sig. } & \multicolumn{2}{|c|}{$\begin{array}{c}\text { Collinearity } \\
\text { Statistics }\end{array}$} \\
\hline & & $B$ & Std. Error & & & & Tolerance & VIF \\
\hline \multirow[t]{7}{*}{6} & (Constant) & 3.372 & .206 & & 16.333 & .000 & & \\
\hline & Formal policies & -.251 & .074 & -.131 & -3.397 & .001 & .987 & 1.013 \\
\hline & Informal policies & -.348 & .058 & -.244 & -5.960 & .000 & .882 & 1.134 \\
\hline & Hours spent on household chores & .306 & .038 & .374 & 8.051 & .000 & .685 & 1.460 \\
\hline & hours spent on children & .055 & .020 & .110 & 2.693 & .007 & .889 & 1.125 \\
\hline & hours spent on dependent & .162 & .034 & .211 & 4.708 & .000 & .736 & 1.358 \\
\hline & Gender & .318 & .056 & .226 & 5.725 & .000 & .948 & 1.055 \\
\hline
\end{tabular}

a. Dependent Variable: Family demand

As can be seen in table 4, $t$ values are significant for all predictor variables $(p<.05)$ indicating coefficients for all variables are not zero and thus predictors were making a significant contribution to the model. Hours spent on household chores $(t(480)=8.05, p<.001)$, hours spent on childcare $(t(480)=2.69, p<.01)$, hours spent on dependent $(t(480)=4.71, p<.001)$, formal policies $(t(480)=-$ $3.40, p<.01)$, informal practice $(t(480)=-5.96, p<.001)$ and gender $(t(480)=5.72, p<.001)$ were all significantly influencing family demand.

In addition, Independent sample $t$-test was executed to see family demand differences in dualcareer families. The effect- size is measured using Cohen's $d$ describing the value of 0.20 is indicative of small-effect whilst 0.50 as an indicative of medium-effect and 0.80 is of larger-effect (Cohen, 1992). The results of the independent sample t-test are presented in Table 5. As can be seen in the bottom of the same Table, Levene's test is not significant, and thus, the study met the assumption of equal variance $(F=7.060 ; p=.08)$. As shown in the same Table, in dual-career families, on average females $(M=4.58, S D=.57)$ reported a greater family demand than males $(M=4.06, S D=.67)$ and the difference is significant $t(260)=-6.871, p<.05$ emphasising a large-sized effect $d=.847$.

Table 5: Family Demand among Dual-career Families

\begin{tabular}{cllccccccc}
\hline \hline Variables & & $\boldsymbol{N}$ & df & Mean & $\boldsymbol{S D}$ & $\boldsymbol{S E}$ & $\boldsymbol{t}$ & Sig. & Cohen's $\boldsymbol{d}$ \\
\hline Family demand & Male & 112 & & 4.06 & .67 & .06 & & & \\
& Female & 150 & 260 & 4.58 & .57 & .05 & -6.871 & .00 & .847 \\
\hline \hline
\end{tabular}

Levene's Test for Equality of Variances $(F=7.060 ; p=.08)$

Further, one way ANOVA was applied to find out whether the variables' means are different in terms of marital status. As the total number of respondents on each group of marital status is very different, Hochberg's GT2 test was employed. The results revealed that family demand across marital status was different indicating that reported mean value was greater for widow $(M=4.48$, $S E=.13)$, followed by married $(M=4.28, S E=.04)$, single $(M=4.20, \mathrm{~S} E=.09)$ and widower $(M=4.10$, $S E=.27$ ). Since Levene's test was not significant $P>.05$, the assumption of equal variance assumed was supported and hence, Hochberg's GT2 was used to find out whether the means difference are 
significant or not. There was not enough evidence to support the effect of marital status on family demand: $F(3,483)=.997, p=.394, \omega=.00$ and Hochberg's GT2 was not significant at all level of marital status.

\section{DISCUSSION}

The primary aim of the study was to investigate the significant contributors of the family demand. The results of the correlation analysis disclosed that hours spent on household chores, number of children, hours spent on children, main child's carer (respondents), working spouse, spouse working hours and gender were significantly positively associated with family demand. It implies that respondents spent time on household chores, cares on children and dependents increase the family demand. Similarly, the number of children, working spouse and spouse working hours also increase the family demand. As expected, females have reported a greater amount of family demand than males spelling out the prevalence of traditional gender role ideology. Further, the results averred that family demand is significantly greater among married working females in dualcareer families implying double burden of females in the society. The present study further found that hours spent on household chores, hours spent on childcare, hours spent on dependents, and gender have significantly impacted on family demand. Of those predicting variables, hours spent on household chores had the largest impact on family demand, followed by gender, hours spent on dependents, and hours spent on children. It implies that hours spent on household chores, childcare and dependents influence family demand whereas the availability of the work-life formal and informal policies supports in managing their family demand. The study further revealed that females experience a greater amount of family demand than males and thus its relationship disclosed a negative effect. Taken all these predictors together, the model contributed $29 \%$ of variance in family demand. Crucially, number of children, number of dependents, marital status and age were not found as predictors of family demand, however many seminal studies conducted in the West confirmed such variables relationship with family demand (e.g. Boyar et al., 2008; Grazywacz \& Marks, 2000). Notwithstanding, this study found that hours spent with children and dependents significantly influenced family demand. This might be attributed to the fact that in an extended family structure, family member(s) living in a household, share responsibilities in looking after children/ dependents, and ipso facto counting the number of children/dependents needing care would be irrelevant in this specific culture rather than hours of engagement. For the same reason being married was also not directly related to family demand.

\section{THEORETICAL CONTRIBUTIONS AND IMPLICATIONS FOR HRM PRACTICE}

The presented study has extended the previous study conducted in the sphere of family demand and work-family conflict (e.g. Fu \& Shaffer, 2001, Boyar et al., 2008) by establishing determinants of family demand in the collectivist culture, Sri Lanka. As discussed earlier, findings from Western studies limit its generalisability to diverse cultural contexts. For instance, extended family structure, traditional gender role ideology, male dominance (men's "headship" and women's "submission") are unique qualities of the collectivist culture (Hofstede et al., 2010; Fernando \& Cohen, 2011). Therefore, the factors determining family demand and strengths of their relationships vary, that has implications in explaining the link between family-related factors and family demand and consequent strategies in alleviating family demand. To the best of researcher's 
knowledge, this is the first systematic study that has identified the contributors of the family demand and thus, the present study filled a void left by the earlier studies. The present study made another contribution by affirming women position in a collectivist culture. Families are increasingly diverging from the traditional male- breadwinner and female- homemaker model as women are increasingly drawn into the labour market and raise their aspirations for educational attainment, careers and financial independence (e.g. Kulik, 2004; Lafreniere \& Longman, 2008). Nonetheless, in a collectivist culture, while females are in labour force, their family responsibilities have not been reduced in which females still perceive family responsibilities as a central role and work as essential for economic benefits especially in developing collectivist nation. Therefore, the traditional gender role ideology suggesting male- breadwinner and female- homemaker is still dominant.

The findings have many useful implications for human resource management (HRM) practices and possibilities of transferring Western human resource solutions. Many studies support that family demand interferes with the performance of work (e.g. Boyar et al., 2008; Fu \& Shaffer, 2001) and therefore, HR managers and practitioners should think of designing workable strategic solutions for alleviating the burden of family demand. Most importantly, the study disclosed the formal work-life policies ameliorate WFC; however the formal work-life policies commonly found in the West are not present in banking organisations in Sri Lanka such as temporal and operational flexible work options, compressed, financial work-family benefits, rearranging work schedules, taking work home, bringing children to work, childcare, eldercare, telecommuting and flexible career paths (e.g. Allen, 2001; Bailey \& Kurland, 2002; Baltes, Briggs, Huff, Wright, \& Neuman, 1999; Behson, 2002; Goodstein, 1995; Honeycutt \& Rosen,1997; Kossek \& Nichol, 1992). Some are not appropriate owing to the cultural differences, for example, the demands of childcare are not so important in an extended family structure as in a nuclear family structure (e.g. Allen, 2001; Baltes et al., 1999; Goff et al., 1990; Goodstein, 1995; Honeycutt \& Rosen, 1997; Kossek \& Nichol, 1992). Thus, organisations should consider appropriate formal policies to reduce WFC in line with cultural differences rather than practising the work-life policies found in the West. For instance, in less developed economies, financial work-family benefit (e.g. Milliken, Martins, \& Morgan, 1998), part-time working (e.g. Edwards \& Robinson, 2001) or medical care support for extended family members could be crucial although research is needed to clarify what is required. Therefore, findings aver the needs for more robust work-life policies in balancing family demand. Beyond these formal policies, informal practices reduce the family demand such as allowing lateness to work or early going home to deal with family problems. However, informal practices are available at superiors' discretion in organisations. Therefore, managers should make sure that informal family demand reduction means are available for the employees without any discrimination. Moreover, management can work out in an ad hoc manner in response to employees demand. Therefore, a better understanding of employee's credibility and family background would facilitate better use of informal policy privilege. On balance, it is advisable that the organisations should design and revitalise tailor-made policies by understanding employee's needs. Importantly, policies for promoting male's participation in family domain are crucial among dual-career families thereby broadening equal opportunities that can balance the responsibilities at home and workplace.

Although the present study has much strength in theoretical and methodological rigour, the important limitations should be acknowledged. The prime limitation of the study was the crosssectional design in which making a causal relationship is debatable. Therefore, time-lagged 
approach / longitudinal design could be useful. In addition, a single-source and self-report survey data might be a portent of common method variance and therefore, multi-source approach is recommended. The present study looked at one sector in depth and ipso facto, the present study should be replicated across other occupations and countries. Further, an in-depth qualitative study is requested for understanding the needs of the support that the employees expect from their organisations prior to designing any policies.

\section{REFERENCES}

Adams, G. A., King, L. A., \& King, D. W. (1996). Relationships of job and family involvement, family social support, and work-family conflict with job and life satisfaction. Journal of Applied Psychology, 81(4), 411-420.

Adams, J., Khan, H. T., Raeside, R., \& White, D. (2007). Research methods for graduate business and social science students. London: Sage publications Ltd.

Agarwala, T., Arizkuren-Eleta, A., Del Castillo, E., Muniz-Ferrer, M., \& Gartzia, L. (2014). Influence of managerial support on work-life conflict and organizational commitment: An international comparison for India, Peru and Spain. The International Journal of Human Resource Management, 25(10), 1460-1483.

Allen, T. D. (2001). Family-supportive work environments: The role of organizational perceptions. Journal of Vocational Behavior, 58(3), 414-435.

Annor, F., \& Burchell, B. (2018). A cross-national comparative study of work demands/support, work-to-family conflict and job outcomes: Ghana versus the United Kingdom. International Journal of Cross Cultural Management, 18(1), 53-72.

Bailey, D. E., \& Kurland, N. B. (2002). A review of telework research: Findings, new directions, and lessons for the study of modern work. Journal of Organizational Behavior, 23(4), 383-400.

Baltes, B. B., Briggs, T. E., Huff, J. W., Wright, J. A., \& Neuman, G. A. (1999). Flexible and compressed workweek schedules: A meta-analysis of their effects on work-related criteria. Journal of Applied Psychology, 84(4), 496-513.

Behson, S. J. (2002). Coping with family-to-work conflict: The role of informal work accommodations to family. Journal of Occupational Health Psychology, 7(4), 324-341.

Blumberg, B., Cooper, D., \& Schindler, P. (2008). Business research method (2 ${ }^{\text {nd }}$ ed.). Maidenhead: McGraw-Hill Education.

Boyar, S. L., Carr, J. C., Mosley Jr, D. C., \& Carson, C. M. (2007). The development and validation of scores on perceived work and family demand scales. Educational and Psychological Measurement, 67(1), 100-115.

Boyar, S. L., Maertz Jr, C. P., Mosley Jr, D. C., \& Carr, J. C. (2008). The impact of work/family demand on work-family conflict. Journal of Managerial Psychology, 23(3), 215-235.

Carlson, D. S. (1999). Personality and role variables as predictors of three forms of work-family conflict. Journal of Vocational Behavior, 55(2), 236-253.

Carlson, D. S., Kacmar, K. M., \& Williams, L. J. (2000). Construction and initial validation of a multidimensional measure of work-family conflict.Journal of Vocational Behavior, 56(2), 249-276.

Chau, S. L. (2019). The impact of work-family conflict on work stress and job satisfaction among Macau table game dealers. International Journal of Tourism Sciences, 1-17. doi:10.1080/15980634.2019.1592298 
Choi, J. (2008). Work and family demands and life stress among Chinese employees: The mediating effect of work-family conflict: Work and family demands and life stress among Chinese employees. The International Journal of Human Resource Management, 19(5), 878-895.

Cohen, J. (1992). Statistical power analysis. Current Directions in Psychological Science, 1(3), 98-101.

Cooke, R. A., \& Rousseau, D. M. (1984). Stress and strain from family roles and work-role expectations. Journal of Applied Psychology, 69(2), 252-260.

Dasgupta, S. D. (1998). Gender roles and cultural continuity in the Asian Indian immigrant community in the US. Sex Roles, 38(11-12), 953-974.

Fernando, W. D. A., \& Cohen, L. (2011). Exploring the interplay between gender, organizational context and career: A Sri Lankan perspective. Career Development International, 16(6), 553-571.

Edwards, C. Y., \& Robinson, O. (2001). "Better” part-time jobs? A study of part-time working in nursing and the police. Employee Relations, 23(5), 438-454.

Emslie, C., \& Hunt, K. (2009). 'Live to work' or 'work to live'? A qualitative study of gender and work-life balance among men and women in mid-life. Gender, Work \& Organization, 16(1), 151-172.

Foley, S., Hang-Yue, N., \& Lui, S. (2005). The effects of work stressors, perceived organizational support, and gender on work-family conflict in Hong Kong. Asia Pacific Journal of Management, 22(3), 237-256.

Frone, M. R., Russell, M., \& Cooper, M. L. (1992). Antecedents and outcomes of work-family conflict: Testing a model of the work-family interface. Journal of Applied Psychology, 77(1), 65-78.

Frone, M. R., Russell, M., \& Cooper, M. L. (1997). Relation of work-family conflict to health outcomes: A four-year longitudinal study of employed parents. Journal of Occupational and Organizational Psychology, 70(4), 325-335.

Fu, C. K., \& Shaffer, M. A. (2001). The tug of work and family: Direct and indirect domainspecific determinants of work-family conflict. Personnel Review, 30(5), 502-522.

Goff, S. J., Mount, M. K., \& Jamison, R. L. (1990). Employer supported child care, work/family conflict, and absenteeism: A field study. Personnel Psychology, 43(4), 793-809.

Goodstein, J. (1995). Employer involvement in eldercare: An organizational adaptation perspective. Academy of Management Journal, 38(6), 1657-1671.

Greenhaus, J. H., \& Beutell, N. J. (1985). Sources of conflict between work and family roles. Academy of Management Review, 10(1), 76-88.

Grzywacz, J. G., \& Marks, N. F. (2000). Reconceptualizing the work-family interface: An ecological perspective on the correlates of positive and negative spillover between work and family. Journal of Occupational Health Psychology, 5(1), 111-126.

Gutek, B. A., Searle, S., \& Klepa, L. (1991). Rational versus gender role explanations for workfamily conflict. Journal of Applied Psychology, 76(4), 560-568.

Hair Jr, J. F., Black, W. C., Babin. B. J., \& Anderson, R. E (2010). Multivariate Data Analysis ( $7^{\text {th }}$ ed.). Englewood Cliffs, NJ: Prentice Hall.

Hammer, L. B., Allen, E., \& Grigsby, T. D. (1997). Work-family conflict in dual-earner couples: Within-individual and crossover effects of work and family. Journal of Vocational Behavior, 50(2), 185-203.

Hassan, Z., Dollard, M. F., \& Winefield, A. H. (2010). Work-family conflict in East vs Western countries. Cross Cultural Management: An International Journal, 17(1), 30-49. 
Hobfoll, S. E. (1989). Conservation of resources: A new attempt at conceptualizing stress. American Psychologist, 44(3), 513-524.

Hofstede, G., Hofstede, G. J., \& Minkov, M. (2010). Cultures and organizations: Software of the mind ( $3^{\text {rd }}$ ed.). New York: McGraw-Hill.

Honeycutt, T. L., \& Rosen, B. (1997). Family friendly human resource policies, salary levels, and salient identity as predictors of organizational attraction. Journal of Vocational Behavior, 50(2), 271-290.

Hoobler, J. M., Wayne, S. J., \& Lemmon, G. (2009). Bosses' perceptions of family-work conflict and women's promotability: Glass ceiling effects. Academy of Management Journal, 52(5), 939-957.

Kelloway, E. K., Gottlieb, B. H., \& Barham, L. (1999). The source, nature, and direction of work and family conflict: A longitudinal investigation. Journal of Occupational Health Psychology, 4(4), 337-346.

Kopelman, R. E., Greenhaus, J. H., \& Connolly, T. F. (1983). A model of work, family, and interrole conflict: A construct validation study. Organizational Behavior and Human Performance, 32(2), 198-215.

Kossek, E. E., \& Nichol, V. (1992). The effects of on-site child care on employee attitudes and performance. Personnel Psychology, 45(3), 485-509.

Kossek, E. E., \& Ozeki, C. (1998). Work-family conflict, policies, and the job-life satisfaction relationship: A review and directions for organizational behavior-human resources research. Journal of Applied Psychology, 83(2), 139-149.

Kulik, L. (2004). Predicting gender role ideology among husbands and wives in Israel: A comparative analysis. Sex Roles, 51(9-10), 575-587.

Lafreniere, S. L., \& Longman, K. A. (2008). Gendered realities and women's leadership development: Participant voices from faith-based higher education. Christian Higher Education, 7(5), 388-404.

Lambert, E. G., Qureshi, H., Keena, L. D., Frank, J., \& Hogan, N. L. (2019). Exploring the link between work-family conflict and job burnout among Indian police officers. The Police Journal, 92(1), 35-55.

Lee, D. J., Grace, B. Y., Sirgy, M. J., Singhapakdi, A., \& Lucianetti, L. (2018). The effects of explicit and implicit ethics institutionalization on employee life satisfaction and happiness: The mediating effects of employee experiences in work life and moderating effects of work-family life conflict. Journal of Business Ethics, 147(4), 855-874.

Lu, L., Gilmour, R., Kao, S. F., \& Huang, M. T. (2006). A cross-cultural study of work/family demands, work/family conflict and wellbeing: the Taiwanese vs British. Career Development International, 11(1), 9-27.

Milliken, F. J., Martins, L. L., \& Morgan, H. (1998). Explaining organizational responsiveness to work-family issues: The role of human resource executives as issue interpreters. Academy of Management Journal, 41(5), 580-592.

Mortazavi, S., Pedhiwala, N., Shafiro, M., \& Hammer, L. (2009). Work-family conflict related to culture and gender. Community, Work \& Family, 12(2), 251-273.

Nameda, A. (2013). Sense of fairness in the division of labor in close relationships: Procedure and gender role ideology. Japanese Psychological Research, 55(1), 33-44.

Netemeyer, R. G., Boles, J. S., \& McMurrian, R. (1996). Development and validation of workfamily conflict and family-work conflict scales. Journal of Applied Psychology, 81(4), 400-410. 
Oishi, A. S., Chan, R. K., Wang, L. L. R., \& Kim, J. H. (2015). Do part-time jobs mitigate workers’ work-family conflict and enhance wellbeing? New evidence from four East-Asian societies. Social Indicators Research, 121(1), 5-25.

Pan, S. Y., \& Yeh, Y. J. (2019). The crossover effect of work-family conflict among hotel employees. International Journal of Contemporary Hospitality Management, 31(2), 812829.

Poster, W. R., \& Prasad, S. (2005). Work-family relations in transnational perspective: A view from high-tech firms in India and the United States. Social Problems, 52(1), 122-146.

Schieman, S., Whitestone, Y. K., \& Van Gundy, K. (2006). The nature of work and the stress of higher status. Journal of Health and Social Behavior, 47(3), 242-257.

Shockley, K. M., Douek, J., Smith, C. R., Peter, P. Y., Dumani, S., \& French, K. A. (2017). Crosscultural work and family research: A review of the literature. Journal of Vocational Behavior, 101, 1-20.

Voydanoff, P. (2005). Toward a conceptualization of perceived work-family fit and balance: A demands and resources approach. Journal of Marriage and Family, 67(4), 822-836.

Williams, K. J., \& Alliger, G. M. (1994). Role stressors, mood spillover, and perceptions of workfamily conflict in employed parents. Academy of Management Journal, 37(4), 837-868.

Yang, N., Chen, C. C., Choi, J., \& Zou, Y. (2000). Sources of work-family conflict: A Sino-US comparison of the effects of work and family demands. Academy of Management Journal, 43(1), 113-123.

Zhao, K., Zhang, M., \& Foley, S. (2019). Testing two mechanisms linking work-to-family conflict to individual consequences: do gender and gender role orientation make a difference?. The International Journal of Human Resource Management, 30(6), 988-1009. 